\title{
Internationalization of Higher \\ Education-What Can Research \\ Add to the Policy Debate? \\ [Overview Paper]
}

\author{
Hans de Wit, Ligia Deca and Fiona Hunter
}

\section{Introduction}

Since its beginnings, the Bologna Process was placed in the context of European and international cooperation, and in particular it was intended to strengthen the competitiveness and attractiveness of the European Higher Education by fostering the students' mobility and creating the framework for the international dimension of higher education. A first concrete step in this direction was made at the Ministerial conference in May 2007 in London, where Ministers adopted the strategy "The European Higher Education Area in a Global Setting", encompassing the following priorities:

- improving information on the European Higher Education Area,

- promoting European Higher Education to enhance its world-wide attractiveness and competitiveness,

- intensifying policy dialogue,

- strengthening cooperation based on partnership and

- furthering the recognition of qualifications (London Communiqué Bologna Process 2007).

Until the Ministerial Conference of 2009, the main focus in mobility was on overcoming obstacles, and it was at that conference when the Ministers decided that

\footnotetext{
H. de Wit $(\square) \cdot$ F. Hunter

Centre for Higher Education Internationalisation (CHEI),

Università Cattolica del Sacro Cuore, Milan, Italy

e-mail: j.w.m.de.wit@hva.nl

F. Hunter

e-mail: fionajanehunter@gmail.com

L. Deca

University of Luxembourg, Luxembourg, Luxembourg

e-mail: ligia.deca@uefiscdi.ro
}

A. Curaj et al. (eds.), The European Higher Education Area,

DOI 10.1007/978-3-319-20877-0_1 
"In 2020, at least $20 \%$ of those graduating in the European Higher Education Area should have had a study or training period abroad." (Communiqué of the Conference of European Ministers Responsible for Higher Education 2009). Three years later, the need to increase the competitiveness and attractiveness of the EHEA was again very high on the agenda of the Bologna Process Ministerial Conference in Bucharest, Romania, in 2012. Discussions on these subjects resulted in adopting a "Mobility for better learning"1 Strategy - as an annex to the Ministerial Communique - and thus agreeing that all member countries would develop and implement their own internationalization and mobility strategies with concrete aims and measurable mobility targets, in order to contribute to the achievement of the EHEA objectives.

Converging with this document, the European Commission launched "The European higher education in the world" strategy (European Commission 2013) to promote mobility and cooperation between the member states and the non-EU countries. According to this policy document, "a comprehensive internationalisation strategy should cover key areas grouped into the following three categories: international student and staff mobility; the internationalisation and improvement of curricula and digital learning; and strategic cooperation, partnerships and capacity building. These categories should not be seen as isolated but as integrated elements of a comprehensive strategy." (EU Communication 2013). With that document, the importance of internationalisation of the curriculum and learning outcomes for all students, received a central place next to mobility, in the European policies for internationalisation of higher education.

This introductory paper provides the context for the following research articles, which were presented at the Second Bologna Researchers Conference, Bucharest, 24-26 November 2014, as well as a brief overview of their main foci and findings.

\section{Its Development}

The strategic notion and concept of 'internationalisation' date from the 1990s. Before, there was already a substantial tradition of research and practice on the international dimension of higher education, in general under the term 'international education', or under terms that reflect some kind of international activity. Basically these traditional terms were either related to mobility, such as study abroad, exchanges, international students or academic mobility, or related to curriculum, such as multicultural education, international studies, peace education, area studies. These terms described a concrete element of international education and later internationalisation, and in many cases were used as pars pro tot and as a synonym for the overall term.

\footnotetext{
${ }^{1}$ http://www.ehea.info/Uploads/\%281\%29/2012\%20EHEA\%20Mobility\%20Strategy.pdf.
} 
The use of 'internationalisation' in relation to higher education already can be noticed in publications in the 1970s. But it is only in the 1990s that the term 'internationalisation' really takes over from 'international education' as describing the different ways the international dimensions in higher education are taking shape. This shift is a reflection of the increasing importance of these international dimensions in higher education and of the related transfer from a marginal set of programs and activities to a more comprehensive process. In Europe, this shift was very much stimulated by the research programmes and mobility schemes, in particular ERASMUS, of the European Commission.

Internationalisation over the past forty years, since the start of the first European programmes (following initiatives in some countries such as Sweden and Germany), has moved from a reactive to a pro-active strategic issue, from added value to mainstream, although in many cases still more in intention and discourse than in practice. It also has seen its focus, scope and content evolve substantially. Increasing competition in higher education, the commercialisation and the increased cross-border delivery of higher education have challenged the value traditionally attached to cooperation in the form of exchanges and partnerships. At the same time, the internationalisation of the curriculum and the teaching and learning process (also referred to as 'Internationalisation at Home') has become as relevant as the traditional focus on mobility (both degree mobility and mobility as part of the home degree). Recent theoretical developments regarding 'Internationalisation at Home' outline that this term 'relates both to formal and informal curriculum, and aims to develop international and intercultural knowledge, skills and attitudes for all students regardless of whether they also take part in mobility opportunities.' (Beelen and Jones, present chapter).

Over the past 40 years, internationalisation of higher education has taken several forms and accents. In the nineteen seventies and early eighties, internationalisation in many countries was focused primarily on development cooperation and aid. In the second half of the nineteen eighties, internationalisation took a different direction. In most of continental Europe, thanks to the development of scholarship programmes and mobility schemes, in particular the ERASMUS programme, the emphasis focused from aid to exchange of students and teachers, as well as curriculum development. In countries like the United Kingdom and Australia, on the contrary, the emphasis shifted from aid to trade. Instead of scholarships, universities were forced by their governments to charge full cost fees to international students. Against all expectations, it has been surprising to see that this did not result in a decrease of international students but in a substantial increase, making the United Kingdom the number 2 and Australia the number 5 country in receiving international students who want to pursue a full degree abroad, behind the United States and close to Germany and France.

In the nineties, influenced among others by the Asian economic crisis - as the large majority of their international students come from these countries-Australia and the United Kingdom took the lead in a new direction of internationalisation, referred to as transnational education, cross-border delivery of education or offshore education. Their universities developed branch campuses and franchise operations 
in countries like Singapore, Malaysia, Vietnam, South Africa and so on. A shift in movement from students to the movement of programs and universities. Together with the United States, Australia and the United Kingdom are the leading nations in international higher education by their inflow of international students and their offshore activities. This shift in internationalisation, which has evolved further in the past decade, is referred to as a shift in paradigm from cooperation to competition, a more commercial approach to international higher education.

In continental Europe, this more commercial approach was originally seen with rather negative eyes. Free or low tuition fees higher education was and still is more common there, and that applied until recently also to students from outside the European Union. We see in the past few years also in continental Europe (Denmark, Sweden, The Netherlands in particular) a move to full cost fees for international students from outside of the EU, and there is an increasing pressure on national tuition fees.

Recently though, we also notice a reaction on the strong commercial focus in international education. The higher education sector has understood that too much of a commercial approach will jeopardize the quality of education, the reputation of the institutions, and by that the future inflow of national and international students. This implies more selection on international students, accreditation and quality control of their offshore operations, transfer of revenues to better facilitate, counselling and guidance of international students, and more emphasis on the internationalisation of their curriculum and on study abroad of the own students. Furthermore, ethical guides for cross-border activities were developed by international organisations, such as the International Association of Universities' 'Affirming Academic Values in Internationalization of Higher Education: A Call for Action', adopted in April 2012. The link between ethical considerations and internationalisation policies is increasingly seen as essential to ensure sustainable development, not only within the higher education sector, but also in society as a whole.

Finally, we also see a shift in geographical sense. The traditional divide between North and South and East and West of the past century is no longer to be taken for granted. The increasing importance of Asia, the developments in the Middle East, Latin America and Africa change also the higher education landscape and by that its international dimension. They bring new values, new approaches and new relations.

It would be too easy, however, to assume that everything has changed over the years with regard to the internationalisation of higher education, and that this change is primarily from a more cooperative model to a more competitive model. There are different accents and approaches. Competing trends exert contrasting pressures on higher education institutions and their internationalisation efforts: national priorities versus International trends; government steering versus institutional autonomy; diversification versus harmonization; competition versus cooperation; intellectual property versus open source (Guri-Rosenblit, present chapter). Internationalisation strategies are filtered and contextualised by the specific internal context of the university, by the type of university, and how it is embedded nationally. Internationalisation strategies are shaped at the programme level by the 
different relationship these programmes have to market and society. An internationalisation strategy can be substantially different for a teacher training programme than for a school of dentistry or a business school. And internationalisation strategies may be different by level: PhD, master and bachelor.

In this context, it is not surprising that we see a call for a change of thinking about internationalisation, a move to mainstreaming it within the overall quality of education, a move to a more comprehensive approach and less revenue based. Several indications of this call are at the same time emerging. The essay with the title 'The end of internationalisation' by Brandenburg and de Wit (2011) might have functioned as a wakeup call, but other initiatives developed at the same time. In particular, worth mentioning was the initiative of the International Association of Universities (IAU) to start a discussion about the need to re-examine the concept of internationalisation and define a call for action based on it (IAU 2012a, b, www.iauaiu.net). The group addressed three questions: Are the concept and the definition of internationalisation keeping up with developments in higher education? Is there a shared understanding of the concept? Has internationalisation lost sight of its central purposes? A call for action has been formulated by IAU based on their work (IAU 2012b, www.iau-aiu.net). The Global Surveys on internationalisation of higher education of IAU, as the 4th one of 2014 (Egron-Polak and Hudson 2014) provide valuable input on the perceptions of university leadership in different parts of the world, and on trends in benefits and risks of internationalisation for higher education.

\section{Impact}

More than in numbers of mobile students, the impact of programmes such as ERASMUS has been on the internationalisation and the reform of higher education. ERASMUS has paved the way for the reform of European higher education under the Bologna Process, has been a pilot for its study point scheme ECTS, and was an initiator for the opening up to countries in Central and Eastern Europe to EU-membership, as it is for current aspiring candidate members. The programme stimulated both national governments and institutions of higher education to develop European and international strategies. The new 'ERASMUS+' programme reflects this global approach to ERASMUS and the ambition of the Commission to extend the scope and targets of the programme: an additional 5 million students studying abroad between 2014 and 2020.

In the Bologna Declaration of 1999 and the Lisbon Strategy of 2000, the two dimensions of internationalisation meet: cooperation and competition. On the one hand, both processes emphasise that there should be more cooperation resulting in a European area for higher education and research: 'A Europe of Knowledge'. On the other hand, there is strong emphasis on the argument that this cooperation is required in order to cope with the competition from the United States, Japan and, increasingly, China and other emerging economies. Also, the Communication, 
'European Higher Education in the World', in which the European Commission presents its internationalisation strategy, reflects these two dimensions in the three pillars: mobility, internationalisation at home and cooperation and partnership.

However, there are also other voices speaking about the impacts of more than two and half decades of academic mobility in EU and the EHEA. The CoSMiCE project talks about the links between impacts of student mobility and responses to this phenomenon in the EHEA, as well as about the asymmetric mobility flows in the region (Wulz and Rainer, present chapter), which have been also analysed by other authors (Ferencz, present chapter).

\section{The Future}

The global higher education landscape and its international dimensions are constantly changing. The global competition for talent, the emergence of international branch campuses, growing complexity in cross-border activity and questions raised in the United States on the payment of agents to recruit students are just some of the issues that until recently were not at the forefront of higher education debates. However, these are now high priorities, not only for international educators, but also for university presidents, associations of universities, politicians and other key higher education players around the world.

The emergence of a global higher education space has implications for our way of looking at internationalisation. As the international dimensions of higher education have developed their own momentum and become a global topic of interest, the growing 'globalisation of internationalisation' requires a more nuanced approach to its interpretation and delivery than has hitherto been the case. Western countries have tended to dominate research and discussions on internationalisation, and the flow of students has been largely in their direction. However, as more countries attract inbound students and open up to internationalisation, their experiences offer new perspectives and issues for consideration.

Some of the same questions arise that have long been debated in the West, yet these different contexts offer insights that can inform practice elsewhere, whether related to the student experience or to institutional concerns. Over the past few years East Asia and South East Asia have become key recruiting regions, with Malaysia, Singapore and Thailand, for example, all declaring themselves international education 'hubs'. To this list can be added China, Japan, Korea, India, Brazil, South Africa and the Middle East, among others, and many more if we include international branch campuses of Western universities.

Notions of importing and exporting countries are being turned upside down as students choose study destinations in countries once seen as merely sending students to the West to study. Global mobility flows are increasingly complex, then, offering new opportunities for those able and willing to access them.

Voices from countries with more recent international engagement should be heard as offering new perspectives and dimensions to the existing landscape of 
international education. One such example is the insight on internationalisation as a lever for change, which has been documented for various countries (Sparks et al., present chapter; Hunter, present chapter; Deca 2014).

In essence, internationalisation efforts in higher education need to be focused on moving away from input and output to more of a process and outcome approach to internationalisation, ensuring that students and faculty are prepared and competent for an increasingly global and interconnected society.

In this process of globalisation of internationalisation to be effective, ethical, responsible and sustainable, the following priorities are according to Jones and de Wit (2012) essential:

- Learn from other, non-Western national and cultural contexts, not only through collaborations and transnational programmes, but also through perspectives on internationalisation itself.

- Ensure that no single approach or paradigm dominates the discourse, but take into account the nature of internationalisation as a comprehensive policy process, with all the policy stages that entails.

- See internationalisation not as a goal in itself, but as a contribution to the quality of students' education and research.

- Be more explicit about institutional and individual motivations so that internationalisation objectives and outcomes are clear and measurable, as well as in line with broader strategic goals.

- Pay more attention to faculty and student perspectives.

- Understand better the impact of international and intercultural learning outcomes on student employability, taking into account the perspectives of (international) employers.

- Continue research on the benefits of internationalisation and the impact on students, faculty and administrators.

- Understand better the link between internationalisation and multiculturalism.

\section{Input from the Papers}

These eight papers reflect both the ongoing conceptual debate on and the diversity of internationalisation in higher education in Europe and beyond: diversity by focus (abroad and/or at home), diversity by country and diversity by level and type of institution. Two papers are focused on mobility, two on curriculum and learning outcomes, two on specific countries (Italy and Kazakhstan), another paper on challenges of internationalization for institutions with specific missions and one on internationalisation in the global landscape.

Sarah Guri-Rosenblit talks about the competing pressures that influence the way in which higher education institutions view internationalisation and act to further it. She also talks about the unintended consequences of internationalisation and about the non-negligible effects of the national definition of institutional autonomy. This 
balancing game becomes more complex and there are different ways in which institutions across the world have chosen to deal with the current maze of trends and international policies. This is why internationalisation is also used or seen as a lever for change (Hunter, present chapter), by either national or institutional actors. There are cases in which the top tier institutions in a country and its government decide to pursue a joint strategy to increase the prestige of the national higher education system and to push otherwise unpopular reforms.

At the same time, second-tier higher education institutions, such as universities of applied sciences in the Netherlands, academic colleges in Israel or community colleges in Canada, face different challenges pertaining to their distinct mission when embarking in internationalisation efforts (de Wit, Yemini and Randall). Based on the conclusions of the paper, it seems that despite the potential of such institutions that benefit from culturally diverse student populations, they often have difficulties in tailoring their actions in the field of internationalisation in order to best fit their overall aims and strategies.

Concerns about the impacts of the current mobility flows and the way in which mobility imbalances within the EHEA, but also between the EHEA and other parts of the world, could and should be mitigated, are voiced in two of this chapter's articles (Ferencz, Wulz and Rainer). Institutional, national and regional actors might have different perspectives on this issue (e.g. what is good for Europe might not benefit a certain category of HEIs in terms of student mobility) and the analysis of the existing impacts of internationalization, with a particular focus on mobility of students and programmes, might shed more light on what needs to be considered for future policy making.

Finally, internationalization at home and the development of intercultural competences seem to be issues which are discussed as second-tier concerns in a world pushed by a competitive impetus. However, it is clear that internationalisation of the curriculum and the ability of higher education institutions to actively design programmes that will foster intercultural understanding and trust is part and parcel of new definitions of quality higher education, which is what should drive internationalization in the first place. Two articles in this chapter aim to explore the new theoretical avenues regarding internationalization at home (Beelen and Jones) and the way in which the university social environment influences the acquisition of intercultural competences in Master programmes (Gregersen-Hermans).

What lessons can be learned from these papers and the discussions during the Bologna Researchers Conference? In the first place, internationalisation strategies are influenced by specific drivers and also by context-dependent starting points. National policies in this field should be clear about their intended purposes, as well as about the role of public authorities in supporting HEIs in their efforts to pursue specific purposes. This is key to positioning countries with a clear purpose and intention. It should not, just happen'.

In the second place, specific strategic approaches need to be developed for achieving specific outcomes. For example, in the case of internationalization at home, key aspects to be considered are developing appropriate teaching and learning strategies, strategies for the development of intercultural competences, 
structured staff development strategies, or appropriate and effective assessment strategies. Also, institutional profiles should play a role in defining the most adequate path for internationalisation of higher education institutions with specific missions.

Other lessons are:

- Ethics and internationalization need be embedded in order for higher education to contribute to sustainable development.

- Mobility policies should shift to becoming a European responsibility. If the EHEA goals in this field are to be achieved, all EHEA students should benefit from the same conditions as the EU students. This might mean inter alia access to transparent EHEA-wide information on admission and funding in the different countries and institutions.

- There is need for more evidence-based policy making in the area of internationalization, and also for more willingness to reassess goals based on emerging evidence. For example, mobility imbalances might not be always detrimental to internationalization. Imbalances might need to be addressed, however, when one of the affected parties feels such a need, and in a way that does not limit freedom of movement. EHEA goals in this area (e.g. increased and balanced mobility) might need to be readjusted, as one of the EHEA goals is indeed increased attractiveness, but it is a fact that the most attractive HE systems are rarely seeing balanced mobility flows.

- More research is needed regarding the influence of institutional differentiation and concentration of resources (mergers, alliances) on internationalization trends; internationalization at home; the understanding and the definition of internationalization; effects and uses of mainstream internationalization policies 'at the periphery' (including in both countries and HEIs 'at the periphery').

Open Access This chapter is distributed under the terms of the Creative Commons Attribution Noncommercial License, which permits any noncommercial use, distribution, and reproduction in any medium, provided the original author(s) and source are credited.

\section{References}

Brandenburg, U., \& De Wit, H. (2011). The end of internationalization. In International higher education (Vol. 62, pp. 15-16), Winter 2011. Boston: Boston College Center for International Higher Education.

Communique of the Conference of European Ministers Responsible for Higher Education. (2009). The Bologna process 2020 - The European higher education area in the new decade, 28-29 April, Leaven and Louvain-la-Neuve.

Deca, L. (2014). International norms in the reform of Romanian higher education: A discursive analysis. European Journal of Higher Education, Routledge. doi:10.1080/21568235.2014. 971040

Egron-Polak, E., \& Hudson, R. (2014). Internationalization of higher education: Growing expectations, essential values. IAU 4rd Global Survey Report ed. Paris: IAU. 
European Commission. (2013). Communication European higher education in the world. http:// eur-lex.europa.eu/LexUriServ/LexUriServ.do?uri=COM:2013:0499:FIN:en:PDF

IAU, International Association of Universities. (2012a). Focus, rethinking internationalization. In IAU Horizons (Vol. 17, 3rd edn. + Vol. 18, 1st edn.), February/March 2012. Paris: International Association of Universities.

IAU, International Association of Universities. (2012b). Affirming academic values in internationalization of higher education: A call for action. www.iau-aiu.net. Paris, International Association of Universities.

Jones, E., \& de Wit, H. (2012). Globalization of internationalization: Thematic and regional reflections on a traditional concept. AUDEM: The International Journal of Higher Education and Democracy, 3, 35-54, 2012.

London Communiqué. Bologna Process. (2007). Towards the European higher education area: Responding to challenges in a globalised world. 17-18 May, 2007. https://www.eqar.eu/ fileadmin/documents/bologna/London-Communique-18May2007.pdf 